\title{
Literature Review on Branding Higher Education in Ethiopia
}

\author{
Daniel Sulamo Ombamo \\ Arsi University College of Business and Economics, Department of Marketing Management
}

\begin{abstract}
The purpose of this study is to review the brand literature focusing on higher educational institutions until 2017 so as to identify areas where researches were conducted and further studies are required. Within the concepts brand, branding, brand strategy, brand management, brand equity, academic journals aligned with University, academic institutions, higher education institutions and related issues were scanned. Among all the articles accessed, ten of them were published in reputable brand related articles were considered in this review. The case articles were reviewed based on their respective year of publication, journal name, methodology, and country of the study, findings and recommendation. The review process employed a content analysis. The findings show that the trend of branding in academic institutions is growing. However, the number of published papers in reputable journals is in infant stage. Most of the papers used quantitative methods and collected data from students via convenience sampling. Eventhough few numbers of articles employed probabilistic method; the size of the population was not stated. The research in the area is confined to few developed countries which also lacks a grand conceptual framework in the sector. Therefore, it is advisable to conduct a comprehensive study to fill such gaps through using sound methodology and developing an appropriate framework which can be applied across nations. The major limitation of this review article is that only ten papers were examined of which generalization about the area is not as such important. Therefore, further studies may apply the procedures and investigate the area comprehensively.
\end{abstract}

DOI: $10.7176 / \mathrm{JMCR} / 55-03$

Publication date: April $30^{\text {th }} 2019$

\section{Introduction}

Brand has several benefits for firms, consumers and society. In terms of consumers, brand is a quality indicator and creates awareness for products (Kapferer2008). In terms of firms, brand provides customer loyalty, consistent sales amount and a high profit margin (Kotler and W. Pfoertsch. 2006; K. L. Keller, 2001). As a result of consumer and firm benefits, brand plays a key role on social development. In intense competence conditions, firms need to create strong brands in order to survive and gain a competitive advantage.

For both goods and services, brands are found to fulfill the same basic functions, in terms of representing a distinctive value system, relevant to consumers (de Chernatony and Segal-Horn (2003) and by Dall'olmo Riley and de Chernatony (2000). They propose a notion of "the service brand" as a holistic process which provides focus to the internal relationship between the service company and the employees, and comes alive in the external relationship (encounter) between consumer and service provider (employee). A virtuous circle is created whenever a strong "brand as a company" identity permeates the organization and provides a relevant focus to both consumers and employees.

Brand is a firm asset that contributes identity and character, guides consumers for product choices and forms the relations among consumers (Kavak ,Bahtşsen ,2015). Along with the movement of goods and general services, the movement of educational services and products has improved significantly in the last decade (Bloom, 2005). Education is increasingly seen not only as an export commodity, but also as a key national brand for a nation's knowledge proficiency (Bano \& Taylor, 2015). Increasing competition between universities heightens the need for institutions to understand, manage, and leverage a strong brand position (Celly \& Knepper, 2010; Hemsley-Brown \& Goonawardana, 2007; Maringe \& Gibbs, 2009). Consequently, more and more universities apply common marketing techniques including brand management to compete effectively (Chapleo, 2011, Hemsley-Brown \& Oplatka, 2006) as cited by Rauschnabel ,Philipp et. al.( 2016).

Though the practice of branding has been emerging in the service sector, literatures in the area are rare. Among the service scopes, education gets attention in the present review. With the purpose to examine the application of brand concepts in higher education sector, systematic literature review approach is used in the present work by classifying the literature on academic branding area until 2017. The review process involved methodological procedures with respective presentation and analysis, conclusion and implication. The literature review is subjected to a content analysis

\section{RESEARCH METHODOLOGY}

Content analysis technique is defined as a systematic, repeated technique for compressing many words of text into fewer content categories based on explicit rules of coding (K. Krippendorff, 1980 ;. P. Weber, 1990). Content analysis helps researches to sieve the large amount of data with easing in a systematic process (U.S. 
General Accounting Office, 1996). Qualitative content analysis or document analysis can be undertaken without engaging with individuals involved in your study (Daymon, Cgristine, 2011). In this paper, all brand related concepts connected to higher education institutions were used to search prior research work in online databases. Those journals and graduate study papers containing a "brand" in their title names, until present time were searched in search engines. Furthermore, systematic categorical classification of investigated articles were summarized by title, year, type of study, research design, data collection method, sampling method, sample size and the country where the studies were conducted.

\subsection{Analysis}

The analysis was made based two consecutive data presentation procedures. In the first part, Table I, the distribution of 21 brand-related papers by year, title, journal name and category were presented. Due to credibility matters, titles which do were no published in reputable journals and categorized as thesis, doctoral dissertation, some without full information of publication were not extended for successive analysis. In the second part, from the twenty one papers, only ten articles published in reputable journals articles were presented in table II for further analysis.

Table I . Distribution of researches by year of pub., title, journal name and category: until 2017

\begin{tabular}{|c|c|c|c|c|c|}
\hline $\mathrm{S}, \mathrm{n}$ & Author & Year & 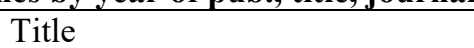 & Journal & Category \\
\hline 1. & $\begin{array}{l}\text { Rauschnabel, } \\
\text { philipp et. Al. }\end{array}$ & 2016 & $\begin{array}{l}\text { Brand management in higher } \\
\text { education: the university brand } \\
\text { personality scale }\end{array}$ & $\begin{array}{l}\text { Journal of business } \\
\text { research }\end{array}$ & article \\
\hline 2. & Menon p, et. Al & $\begin{array}{l}2016 \\
\text { may }\end{array}$ & $\begin{array}{l}\text { Dimensions of brand equity: an } \\
\text { investigation on higher } \\
\text { education institutions }\end{array}$ & $\begin{array}{l}\text { Asian journal of } \\
\text { research in social } \\
\text { sciences and } \\
\text { humanities }\end{array}$ & Article \\
\hline 3. & Shcherbak, et.al & 2016 & $\begin{array}{l}\text { Formation and development of } \\
\text { brand equity of higher education } \\
\text { institution }\end{array}$ & None & Article \\
\hline 4. & $\begin{array}{l}\text { Sylvie lome, } \\
\text { et.al }\end{array}$ & 2016 & $\begin{array}{l}\text { Constructing a national higher } \\
\text { education brand for the UK: } \\
\text { positional competition and } \\
\text { promised capitals }\end{array}$ & $\begin{array}{l}\text { Routlege : taylor and } \\
\text { frances group }\end{array}$ & Article \\
\hline 5. & $\begin{array}{l}\text { Vukasovič, } \\
\text { Tina }\end{array}$ & 2015 & $\begin{array}{l}\text { Managing consumer-based } \\
\text { brand equity in higher education }\end{array}$ & None & Article \\
\hline 6. & Singh, jaywant & 2015 & $\begin{array}{l}\text { Co-branding in higher } \\
\text { education: an investigation of } \\
\text { student attitudes }\end{array}$ & None & Article \\
\hline 7. & Gade, jess, et.al & 2014 & $\begin{array}{l}\text { Higher education branding: } \\
\text { attracting Brazilian talent to } \\
\text { Danish higher education }\end{array}$ & None & Thesis \\
\hline 8. & Bansal sanjeev & $\begin{array}{l}2014 \\
\text { may }\end{array}$ & $\begin{array}{l}\text { Branding an academic } \\
\text { institution: the strategic issues }\end{array}$ & $\begin{array}{l}\text { Journal of international } \\
\text { academic research for } \\
\text { multidisciplinary }\end{array}$ & Article \\
\hline 9. & $\begin{array}{l}\text { Dr. John } 1 \mathrm{~s} . \\
\text { Franklin et.al }\end{array}$ & 2013 & $\begin{array}{l}\text { Factor branding in selection of } \\
\text { higher educational institutions } \\
\text { in india }\end{array}$ & $\begin{array}{l}\text { Journal of business and } \\
\text { management (iosr-jbm) }\end{array}$ & Article \\
\hline 10. & & 2013 & $\begin{array}{l}\text { Designing and explaining brand } \\
\text { equity model in higher } \\
\text { education }\end{array}$ & $\begin{array}{l}\text { European online } \\
\text { journal of natural \& } \\
\text { social sciences }\end{array}$ & Article \\
\hline 11. & Valtere, laura & 2012 & $\begin{array}{l}\text { Branding in higher education: } \\
\text { the concept of brand and key } \\
\text { stakeholders }\end{array}$ & None & Article \\
\hline 12. & Yih, laihuey & 2012 & $\begin{array}{l}\text { A study of brand equity and } \\
\text { institutional image between two } \\
\text { higher educational institutions }\end{array}$ & None & Thesis \\
\hline 13. & Beneke, j.h & 2011 & $\begin{array}{l}\text { Marketing the institution to } \\
\text { prospective students - a review } \\
\text { of brand (reputation) }\end{array}$ & $\begin{array}{l}\text { International journal of } \\
\text { business and } \\
\text { management vol. } 6 \text {, no. } \\
\text { 1; January } 2011\end{array}$ & \\
\hline
\end{tabular}




\begin{tabular}{|c|c|c|c|c|c|}
\hline $\mathrm{S}, \mathrm{n}$ & Author & Year & Title & Journal & Category \\
\hline 14. & $\begin{array}{l}\text { Amboy joy, } \\
\text { victoria }\end{array}$ & 2011 & $\begin{array}{l}\text { Implications of branding } \\
\text { initiatives in higher Education } \\
\text { among trademarked institutions } \\
\text { in California }\end{array}$ & None & $\begin{array}{l}\text { Doctoral } \\
\text { dissertations }\end{array}$ \\
\hline 15. & $\begin{array}{l}\text { Harsha,pragya } \\
\text { p }\end{array}$ & 2011 & $\begin{array}{l}\text { Creating brand value of higher } \\
\text { education institution }\end{array}$ & $\begin{array}{l}\text { Jim, volume } 19, \\
\text { number } 2, \text { July - } \\
\text { December } 2011\end{array}$ & Article \\
\hline 16. & Beneke & 2011) & $\begin{array}{l}\text { Marketing the institution to } \\
\text { prospective students - a review } \\
\text { of brand (reputation) } \\
\text { management in higher education }\end{array}$ & $\begin{array}{l}\text { International journal of } \\
\text { business and } \\
\text { management vol. } 6 \text {, no. } \\
\text { 1; January } 2011\end{array}$ & Articles \\
\hline 17. & $\begin{array}{l}\text { Mourad, maha, } \\
\text { et.al }\end{array}$ & 2010 & $\begin{array}{l}\text { Brand equity in higher } \\
\text { education }\end{array}$ & $\begin{array}{l}\text { Marketing intelligence } \\
\& \text { planning, vol. } 29 \text { no. } \\
\text { 4, } 2011 \text { pp. } 403-420 \\
\text { Emerald group } \\
\text { publishing limited }\end{array}$ & Article \\
\hline 18. & $\begin{array}{l}\text { Beker, christian, } \\
\text { et.al }\end{array}$ & 2009 & $\begin{array}{l}\text { Branding in universities: } \\
\text { identity versus image; case } \\
\text { study of Swedish university }\end{array}$ & No & Thesis \\
\hline 19. & $\begin{array}{l}\text { Kimberly, m. } \\
\text { Judson, et.al. }\end{array}$ & 2009 & $\begin{array}{l}\text { Building a university brand } \\
\text { from within: university } \\
\text { administrators' perspectives of } \\
\text { internal branding }\end{array}$ & $\begin{array}{l}\text { Services marketing } \\
\text { quarterly, 30:54-68, } \\
2009\end{array}$ & \\
\hline 20. & $\begin{array}{l}\text { Jane, hemsley- } \\
\text { brown, et.al }\end{array}$ & 2007 & $\begin{array}{l}\text { Brand harmonization in the } \\
\text { international higher education } \\
\text { market }\end{array}$ & $\begin{array}{l}\text { Journal of business } \\
\text { research, vol. } 60 \mathrm{pp} \\
942-948(20 \mathrm{p}) .\end{array}$ & \\
\hline 21. & Katarzyna, & N.d & $\begin{array}{l}\text { Components of brand of a } \\
\text { higher education institution }\end{array}$ & $\begin{array}{l}\text { Jel classification: } \mathrm{m} 14, \\
\text { m31 }\end{array}$ & Articles \\
\hline
\end{tabular}

Source: Own organization

As seen in table I, of 21 research works, $19 \%$ (4) of the papers were published between 2007 and 2010; whereas $81 \%$ ( 17) were published between 2011 and 2017. This implies that the trend of applying brand concept in higher institutions is increasing through time.

The distribution ratio of the examined studies among the journals indicates that a large portion of the studies on higher education branding were published in marketing and business journals. Among ten papers, only $2(20 \%)$ of the articles were published in journal of business research and $80 \%(8)$ were published in different journals. The remaining studies, which were recent ones, published in journals with fundamental topics such as natural science, social science and multi-disciplinary journals. The fact that journals focusing on different disciplines have published studies on brand in recent years is an indicator that the subject has gained importance in a multidisciplinary aspect.

The table also shows that majority of the researches conducted in the area are related to brand equity with few other concepts such as brand identity and brand reputation. Though there is improvement in the application of the concept in the higher education setting, the number of papers (articles) published in reputable journal is yet in infant stage. This shows the area is not exhaustively investigated in this context.

\subsection{Distribution of the research Paper by approach and type of study}

Table 2, columns 4 and 5 provides the distribution of research papers based on research approach and type of study. From the approach aspect, the share of quantitative approach is $5(50 \%)$, qualitative is $4(40 \%)$ whereas mixed approached contains the lowest size,1(10\%). This shows mixed research is in an infant stage in higher education branding. This is different from the result found by (Bahtıșen ,Kavak, 2015) involved review of 409 journal articles where quantitative, qualitative and mixed design hold $62 \%, 27 \%$ and $34 \%$ respectively 


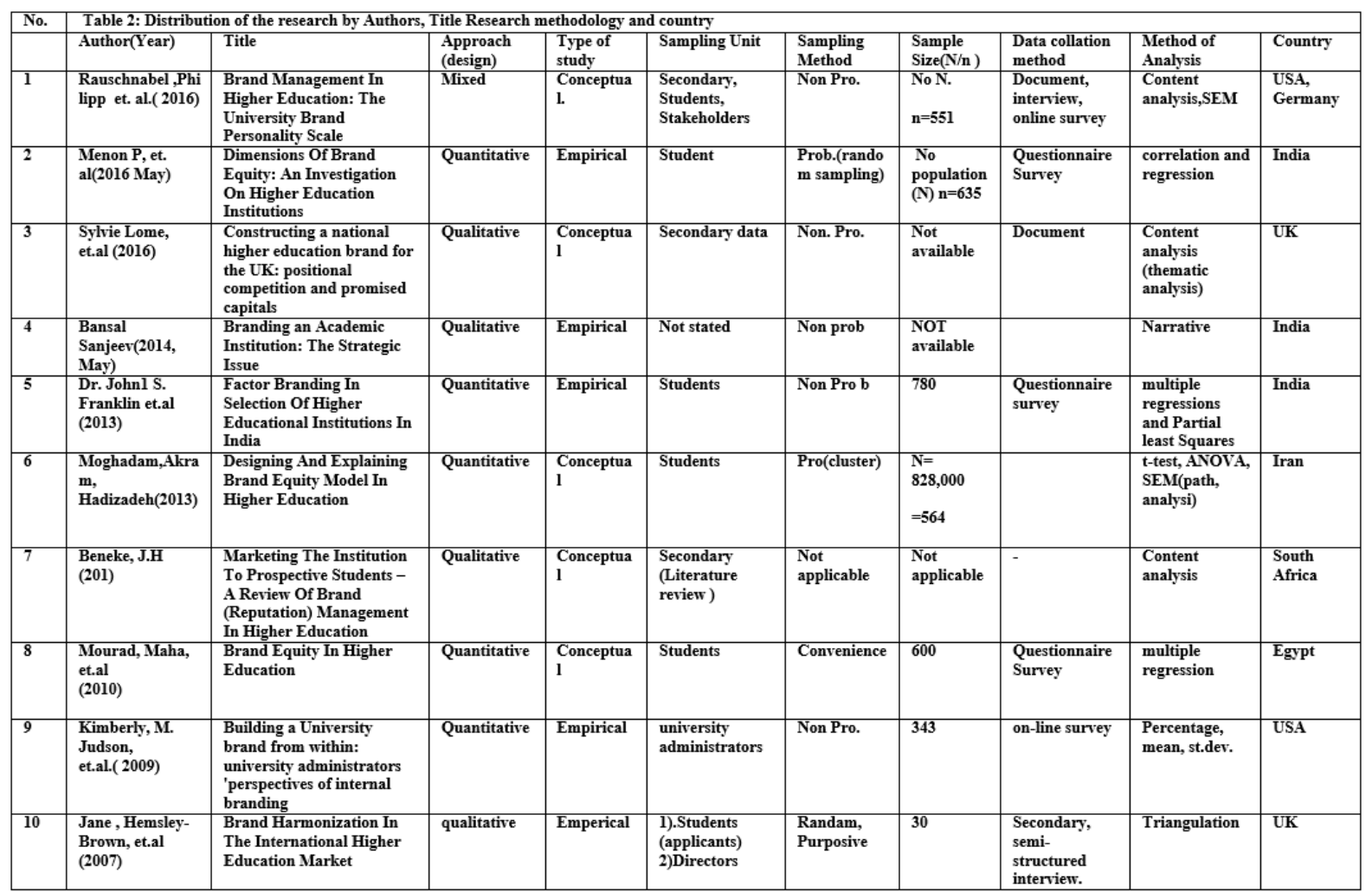

With respect to type of study, the table presents that both the empirical and conceptual models are equivalent. This is in contrast to the finding of Bahtışen, Kavak, (2015), which shows empirical and conceptual researches constitute $84 \%$ and $16 \%$ of the overall study respectively. In the present study conceptual models might be used due to the scarce literatures in the area.

\subsubsection{Distribution of the research Paper by Sampling Units, Method \& size}

As seen in the above table of column 6 , students were widely used units of sampling in educational branding following secondary sources (documents, literatures etc), administrative and managing directors and stakeholders at last.

When it comes to the classification according to the sampling Method, Table 2, of column 7, nonprobability sampling method takes the lion's share followed by probability sampling in the methodology part, Simple random and cluster sampling methods mentioned as probabilistic sampling method; Convenience and purposive sampling methods are mentioned in non-probabilistic method. Even though few numbers of articles employed probabilistic method, the size of the population is not stated.

With regard to sample size, of 10 articles, only 7 papers that give information about the sample are included in this analysis. The sample size of the seven paper ranges from 30 to 780 , where, the average size is 420 .

\subsubsection{Method of data collection and Analysis}

It is revealed from the table that the data collected by quantitative method exceeds the qualitative method of collection. Table 2, column 8 indicates that survey method is frequently used in quantitative data collection whereas interview is a major tool in qualitative methods. Secondary data from documents and literatures were used in both designs.

In the case of articles reviewed, data were analyzed quantitatively through models of SEM, correlation, simple regression, multiple regression, PLS, ANOVA, t-test ,structural model path, percentages, mean and standard deviations. Of the method mentioned, regression and structural equation model were most frequently used one is factor analysis. In addition data which were gathered through survey method were analyzed quantitatively. Content analysis is most frequently used in the qualitative

\subsubsection{Distribution of researches by country}

Among the 10 articles reviewed in the present study. India constitutes 3(33\%), USA and UK 2(20\%) each and the rest three countries contain 30\%. Branding studies in education sector is concentrated in three countries: India, USA, and UK. Studies conducted in these three countries generate the $70 \%$ all studies conducted in 45 countries. Therefore, it can be suggested that to bring as many as discrete perspectives into the brand literature, increasing number of studies should come from different countries 


\section{Results and Recommendations}

In the present study, research papers were classified by year of publication, title, journal name, category, methodology and country of study. The result indicates that most of educational branding research was published between 2011 and 2017 than 2001-2010. This implies that the trend of applying brand concept in higher institutions is increasing through time. Though there is improvement in the application of the concept in the higher education setting, the number of papers (articles) published in reputable journal is in infant stage. Thus, the area is not exhaustively investigated in this context. With regard to the area of concept, majority of the researches focused on brand equity with few other concepts such as brand identity and brand reputation. This indicates brand equity is an important issue in educational setting.

The distribution ratio of the examined studies among the journals indicates that a large portion of the studies on higher education branding were published in marketing and business journals. The remaining studies, which are recent ones, published in journals with fundamental topics such as natural science, social science and multidisciplinary journals. The fact that journals focusing on different disciplines have published studies on brand in recent years is an indicator that the subject has gained importance in a multidisciplinary aspect.

The research papers examined in the study were classified under two fundamental areas based on their approaches and type of study. The result shows that quantitative, qualitative and mixed approaches were used with their respective decreasing proportion. It was evident that the application of mixed research in higher education branding is rare. With regard to type of study, findings of the review paper disclose that both empirical and conceptual models were used proportionally. Thus, conceptual models might be used due to the scarce literatures in the area.

The research papers were distributed by Sampling Units, Method \& size. Accordingly, students were widely used units of sampling in educational branding followed by secondary sources (documents, literatures etc). It is also noticed that the involvement of other external stakeholders is minimal. The result of sampling method examination shows that non probability sampling method took the lion's share followed by probability sampling. In this perspective, Simple random and cluster sampling methods were mentioned as probabilistic sampling method whereas convenience and purposive sampling methods are mentioned in non-probabilistic method. Eventhough few number of articles employed probabilistic method, the size of the population is not stated. From this respect, scientific rule of research about probabilistic research has been ignored. In addition, in some papers, it was stated that stakeholders were used but no information is provided in the findings.

The sample size of the seven paper containing information ranges from 30 to 780 . In gathering data, survey method is frequently used in quantitative data collection whereas interview is a major tool in qualitative methods. Secondary data from documents and literatures were used in both designs. Questionnaire survey and interview are commonly employed instruments in the articles reviewed. Data which are subject to quantitative approach were analyzed by large number of tools; of which, regression and structural equation model were most frequently used. Qualitative data were analyzed through content analysis. However, the triangulation of both quantitative and qualitative tools of analysis is not explicitly noticed.

The country related aspect of researches conducted illustrates that India, USA and UK constitute the larger proportion. According to Cengiz, Hakan (2016), US is also a leading one in brand loyalty research conducted in140 countries. USA and India generate the one-third of all studies conducted in 45 countries (Kavak, Bahtışen,et.al, 2015). It shows the studies of brand concepts are concentrated in very few countries.

\section{Recommendation and Implication}

Academicians and research need to give emphasis to branding services in general and to higher education in particular. It is advisable to conduct a comprehensive study using sound methodology and developing an appropriate framework which can be applied across nations. Future researches ought to apply branding in multidisciplinary areas in addition to marketing fields. The application of rule of probabilistic method, definition of target population and sample size is areas that need attention to fill the gaps seen in the reviewed papers of this study. The future researches need also to involve different stakeholders in addition to students in higher institution branding. The major limitation of this study is that only ten papers were examined of which generalization about the area is not as such important. Therefore, further studies may apply the procedures and investigate the area comprehensively.

\section{Reference}

Celly, K. S., \& Knepper, B. (2010). The California State University: A case on branding the largest public university system in the US. International Journal of Nonprofit and Voluntary Sector Marketing, 15(2), $137-156$.

Cengiz , Hakan (2016), Review of Brand Loyalty Literature: 2001 - 2015,

Chapleo, C. (2011). Branding a university: Adding real value or smoke and mirrors? In M. Molesworth, \& R. Scullion (Eds.), The marketisation of higher education and the student as consumer (pp. 101-114). London: 
Routledge.

Daymon, Christine and Holloway, Immy (2011, Qualitative Research Methods in Public Relations and Marketing DOI: 10.17722/jorm.v6i1.136

De Chernatony, L., and McDonald, M. (2003). Creating powerful brands, third edition. Butterworth-Heinemann, Oxford

Hemsley-Brown, J., \& Oplatka, I. (2006). Universities in a competitive global marketplace: A systematic review of the literature on higher education marketing. International Journal of Public Sector Management, 19(4), 316-338.

Hemsley-Brown, J., and S. Goonawardana. (2007).Brand Harmonization in the International Higher Education Market. Journal of Business Research 60 (9): 942-48.

K. L. Keller(, 2001), Building Customer-Based Brand Equity: A Blueprint for Creating Strong Brands, Marketing Science Institute

Kapfere,( 2008.)r, the New Strategic Brand Management: Creating and Sustaining Brand Equity Long Term, 4th ed., London

Kavak, Bahtş̧en, (2015), A Literature Review on "Brand" in between 2010-2015, International Journal of Trade, Economics and Finance, Vol. 6, No. 6

P. Kotler and W. Pfoertsch (2006), B2B Brand Management, Berlin: Springer,.

R. P. Weber(1990), Basic Content Analysis, 2nd ed. Sage, Newbury Park, CA,

Rauschnabel, P.A., et al.( (2016),), Brand management in higher education: The University Brand Personality Scale, Journal of Business Research http:// dx.doi.org/10.1016/j.jbusres.2016.01.023

Rippendorff, K (1980) Content Analysis: An Introduction to its Methodology, London: Sage,

U.S. General Accounting Office, Content Analysis (1996.): A Methodology for Structuring and Analyzing Written Material, GAO/PEMD-10.3.1. Washington, D.C. 